\title{
Sticky Information Versus Sticky Prices: A Proposal to Replace the New Keynesian Phillips Curve
}

\section{Citation}

Mankiw, N. Gregory, and Ricardo Reis. 2002. Sticky information versus sticky prices: A proposal to replace the new Keynesian Phillips curve. Quarterly Journal of Economics 117(4): 1295-1328.

\section{Published Version}

http://dx.doi.org/10.1162/003355302320935034

\section{Permanent link}

http://nrs.harvard.edu/urn-3:HUL.InstRepos:3415324

\section{Terms of Use}

This article was downloaded from Harvard University's DASH repository, and is made available under the terms and conditions applicable to Other Posted Material, as set forth at http:// nrs.harvard.edu/urn-3:HUL.InstRepos:dash.current.terms-of-use\#LAA

\section{Share Your Story}

The Harvard community has made this article openly available.

Please share how this access benefits you. Submit a story.

Accessibility 


\title{
STICKY INFORMATION VERSUS STICKY PRICES:
}

\section{A PROPOSAL TO REPLACE THE NEW KEYNESIAN PHILLIPS CURVE**}

\author{
N. Gregory Mankiw and Ricardo Reis
}

This paper examines a model of dynamic price adjustment based on the assumption that information disseminates slowly throughout the population. Compared with the commonly used sticky-price model, this sticky-information model displays three related properties that are more consistent with accepted views about the effects of monetary policy. First, disinflations are always contractionary (although announced disinflations are less contractionary than surprise ones). Second, monetary policy shocks have their maximum impact on inflation with a substantial delay. Third, the change in inflation is positively correlated with the level of economic activity.

The dynamic effects of aggregate demand on output and inflation remain a theoretical puzzle for macroeconomists. In recent years, much of the literature on this topic has used a model of time-contingent price adjustment. This model, often called "the new Keynesian Phillips curve," builds on the work of Taylor [1980], Rotemberg [1982], and Calvo [1983]. As the recent survey by Clarida, Gali, and Gertler [1999] illustrates, this model is widely used in theoretical analysis of monetary policy. McCallum [1997] has called it "the closest thing there is to a standard specification."

Yet there is growing awareness that this model is hard to square with the facts. Ball [1994a] shows that the model yields the surprising result that announced, credible disinflations cause booms rather than recessions. Fuhrer and Moore [1995] argue that it cannot explain why inflation is so persistent. Mankiw [2001] notes that it has trouble explaining why shocks to monetary policy have a delayed and gradual effect on inflation. These problems appear to arise from the same source: although the price level is sticky in this model, the inflation rate can change quickly. By contrast, empirical analyses of the inflation process (e.g., Gordon [1997]) typically give a large role to "inflation inertia."

\footnotetext{
* We are grateful to Alberto Alesina, Marios Angeletos, Laurence Ball, William Dupor, Martin Eichenbaum, Christopher Foote, Xavier Gabaix, Mark Gertler, Bennett McCallum, Kenneth Rogoff, Julio Rotemberg, Michael Woodford, and anonymous referees for comments on an earlier draft. Reis is grateful to the Fundacao Ciencia e Tecnologia, Praxis XXI, for financial support.

(C) 2002 by the President and Fellows of Harvard College and the Massachusetts Institute of Technology.

The Quarterly Journal of Economics, November 2002
} 
This paper proposes a new model to explain the dynamic effects of aggregate demand on output and the price level. The essence of the model is that information about macroeconomic conditions diffuses slowly through the population. This slow diffusion could arise because of either costs of acquiring information or costs of reoptimization. In either case, although prices are always changing, pricing decisions are not always based on current information. We call this a sticky-information model to contrast it to the standard sticky-price model on which the new Keynesian Phillips curve is based.

To formalize these ideas, we assume that each period a fraction of the population updates itself on the current state of the economy and computes optimal prices based on that information. The rest of the population continues to set prices based on old plans and outdated information. Thus, this model combines elements of Calvo's [1983] model of random adjustment with elements of Lucas' [1973] model of imperfect information.

The implications of our sticky-information model, however, are closer to those of Fischer's [1977] contracting model. As in the Fischer model, the current price level depends on expectations of the current price level formed far in the past. In the Fischer model, those expectations matter because they are built into contracts. In our model, they matter because some price setters are still setting prices based on old decisions and old information. ${ }^{1}$

After introducing the sticky-information model in Section I, we examine the dynamic response to monetary policy in Section II. In contrast to the standard sticky-price model, which allows for the possibility of disinflationary booms, the sticky-information model predicts that disinflations always cause recessions. In some ways, the dynamic response in the sticky-information model resembles Phillips curves with backward-looking expectations.

1. We should also note several other intellectual antecedents. Gabaix and Laibson [2001] suggest that consumption behavior is better understood with the assumption that households update their optimal consumption only sporadically; it was in fact a presentation of the Gabaix-Laibson paper that started us working on this project. Another related paper is Ball [2000], who tries to explain price dynamics with the assumption that price setters use optimal univariate forecasts but ignore other potentially relevant information. In addition, Rotemberg and Woodford [1997] assume a one-period decision lag for some price setters. Finally, after developing our model, we became aware of Koenig [1997]; Koenig's model of aggregate price dynamics is motivated very differently from ours and is applied to a different range of questions, but it has a formal structure that is similar to the model explored here. 
Yet there is an important difference: in the sticky-information model, expectations are rational, and credibility matters. In particular, the farther in advance a disinflationary policy is anticipated, the smaller is the resulting recession.

In Section III we make the model more realistic by adding a simple yet empirically plausible stochastic process for the money supply. After calibrating the model, we examine how output and inflation respond to a typical monetary policy shock. We find that the sticky-price model yields implausible impulse response functions: according to this model, the maximum impact of a monetary shock on inflation occurs immediately. By contrast, in the sticky-information model, the maximum impact of monetary shocks on inflation occurs after seven quarters. This result more closely matches the estimates from econometric studies and the conventional wisdom of central bankers.

Section IV then examines whether the models can explain the central finding from the empirical literature on the Phillips curve-namely, that vigorous economic activity causes inflation to rise. The standard sticky-price model is inconsistent with this finding and, in fact, yields a correlation of the wrong sign. By contrast, the sticky-information model can explain the widely noted correlation between economic activity and changes in inflation.

The sticky-information model proposed here raises many questions. In Section $\mathrm{V}$ we examine the evidence that might be brought to bear to evaluate the model, and we discuss how one might proceed to give the model a more solid microeconomic foundation. In Section VI we conclude by considering how the model relates to the broader new Keynesian literature on price adjustment.

\section{A Tale of Two Models}

We begin by deriving the two models: the standard stickyprice model, which yields the new Keynesian Phillips curve, and the proposed sticky-information model.

\section{I.A. A Sticky-Price Model: The New Keynesian Phillips Curve}

Here we review the standard derivation of the new Keynesian Phillips curve, as based on the Calvo model. In this model, firms follow time-contingent price adjustment rules. The time for price adjustment does not follow a deterministic schedule, how- 
ever, but arrives randomly. Every period, a fraction $\lambda$ of firms adjust prices. Each firm has the same probability of being one of the adjusting firms, regardless of how long it has been since its last price adjustment.

We start with three basic relationships. The first concerns the firm's desired price, which is the price that would maximize profit at that moment in time. With all variables expressed in logs, the desired price is

$$
p_{t}^{*}=p_{t}+\alpha y_{t} .
$$

This equation says that a firm's desired price $p^{*}$ depends on the overall price level $p$ and output $y$. (Potential output is normalized to zero here, so $y$ should be interpreted as the output gap.) A firm's desired relative price, $p^{*}-p$, rises in booms and falls in recessions.

Although we will not derive this equation from a firm's profit maximization problem, one could easily do so, following Blanchard and Kiyotaki [1987]. Imagine a world populated by identical monopolistically competitive firms. When the economy goes into a boom, each firm experiences increased demand for its product. Because marginal cost rises with higher levels of output, greater demand means that each firm would like to raise its relative price.

In this model, however, firms rarely charge their desired prices, because price adjustment is infrequent. When a firm has the opportunity to change its price, it sets its price equal to the average desired price until the next price adjustment. The adjustment price $x$ is determined by the second equation:

$$
x_{t}=\lambda \sum_{j=0}^{\infty}(1-\lambda)^{j} E_{t} p_{t+j}^{*}
$$

According to this equation, the adjustment price equals a weighted average of the current and all future desired prices. Desired prices farther in the future are given less weight because the firm may experience another price adjustment between now and that future date. This possibility makes that future desired price less relevant for the current pricing decision. The rate of arrival for price adjustments, $\lambda$, determines how fast the weights decline. 
The third key equation in the model determines the overall price level $p$ :

$$
p_{t}=\lambda \sum_{j=0}^{\infty}(1-\lambda)^{j} x_{t-j} .
$$

According to this equation, the price level is an average of all prices in the economy and, therefore, a weighted average of all the prices firms have set in the past. The rate of arrival for price adjustments, $\lambda$, also determines how fast these weights decline. The faster price adjustment occurs, the less relevant past pricing decisions are for the current price level.

Solving this model is a matter of straightforward algebra. We obtain the following:

$$
\pi_{t}=\left[\alpha \lambda^{2} /(1-\lambda)\right] y_{t}+E_{t} \pi_{t+1},
$$

where $\pi_{t}=p_{t}-p_{t-1}$ is the inflation rate. Thus, we obtain the new Keynesian Phillips curve. Inflation today is a function of output and inflation expected to prevail in the next period. This model has become the workhorse for much recent research on monetary policy.

\section{I.B. A Sticky-Information Model}

This subsection proposes an alternative model of price dynamics. In this model, every firm sets its price every period, but firms gather information and recompute optimal prices slowly over time. In each period, a fraction $\lambda$ of firms obtains new information about the state of the economy and computes a new path of optimal prices. Other firms continue to set prices based on old plans and outdated information. We make an assumption about information arrival that is analogous to the adjustment assumption in the Calvo model: each firm has the same probability of being one of the firms updating their pricing plans, regardless of how long it has been since its last update.

As before, a firm's optimal price is

$$
p_{t}^{*}=p_{t}+\alpha y_{t} .
$$

A firm that last updated its plans $j$ periods ago sets the price

$$
x_{t}^{j}=E_{t-j} p_{t}^{*}
$$


The aggregate price level is the average of the prices of all firms in the economy:

$$
p_{t}=\lambda \sum_{j=0}^{\infty}(1-\lambda)^{j} x_{t}^{j} .
$$

Putting these three equations together yields the following equation for the price level:

$$
p_{t}=\lambda \sum_{j=0}^{\infty}(1-\lambda)^{j} E_{t-j}\left(p_{t}+\alpha y_{t}\right) .
$$

The short-run Phillips curve is apparent in this equation: output is positively associated with surprise movements in the price level.

With some tedious algebra, which we leave to the Appendix, this equation for the price level yields the following equation for the inflation rate:

$$
\pi_{t}=\left[\frac{\alpha \lambda}{1-\lambda}\right] y_{t}+\lambda \sum_{j=0}^{\infty}(1-\lambda)^{j} E_{t-1-j}\left(\pi_{t}+\alpha \Delta y_{t}\right),
$$

where $\Delta y_{t}=y_{t}-y_{t-1}$ is the growth rate of output. Inflation depends on output, expectations of inflation, and expectations of output growth. We call this the sticky-information Phillips curve.

Take note of the timing of the expectations. In the standard sticky-price model, current expectations of future economic conditions play an important role in determining the inflation rate. In this sticky-information model, as in Fischer [1977], expectations are again important, but the relevant expectations are past expectations of current economic conditions. This difference yields large differences in the dynamic pattern of prices and output in response to monetary policy, as we see in the next section.

One theoretical advantage of the sticky-information model is that it survives the McCallum critique. McCallum [1998] has criticized the standard sticky-price model on the grounds that it violates a strict form of the natural rate hypothesis, according to which "there is no inflation policy-no money creation schemethat will keep output high permanently." Following Lucas [1972], McCallum argues that "it seems a priori implausible that a nation 
can enrich itself in real terms permanently by any type of monetary policy, by any path of paper money creation." The stickyprice model fails this test because a policy of permanently falling inflation will keep output permanently high. By contrast, the sticky-information model satisfies this strict version of the natural rate hypothesis. Absent surprises, it must be the case that $p_{t}=E_{t-j} p_{t}$, which in turn implies $y_{t}=0$. Thus, the McCallum critique favors the sticky-information Phillips curve over the more commonly used alternative.

\section{Inflation AND Output Dynamics in the StiCKY-INFORMATION MODEL}

Having presented the sticky-information Phillips curve, we now examine its dynamic properties. To do this, we need to complete the model with an equation for aggregate demand. We use the simplest specification possible:

$$
m=p+y,
$$

where $m$ is nominal GDP. This equation can be viewed as a quantity-theory approach to aggregate demand, where $m$ is interpreted as the money supply and log velocity is assumed constant at zero. Alternatively, $m$ can be viewed more broadly as incorporating the many other variables that shift aggregate demand. We take $m$ to be exogenous. Our goal is to examine how output and inflation respond to changes in the path of $m .^{2}$

As we proceed, it will be useful to compare the dynamics of our proposed sticky-information Phillips curve with more familiar models. We use two such benchmarks. The first is the stickyprice model presented earlier, which yields the standard new Keynesian Phillips curve:

$$
\pi_{t}=\beta y_{t}+E_{t} \pi_{t+1},
$$

where $\beta=\left[\alpha \lambda^{2} /(1-\lambda)\right]$ and the expectations are assumed to be formed rationally. The second is a backward-looking model:

$$
\pi_{t}=\beta y_{t}+\pi_{t-1} .
$$

2. There are other, perhaps more realistic, ways to add aggregate demand to this model. One possibility would be to add an IS equation together with an interest-rate policy rule for the central bank. Such an approach is more complicated and involves more free parameters. We believe the simpler approach taken here best illustrates the key differences between the sticky-information model and more conventional alternatives. 
This backward-looking model resembles the equations estimated in the empirical literature on the Phillips curve (as discussed in, e.g., Gordon [1997]). It can be viewed as the sticky-price model together with the assumption of adaptive expectations: $E_{t} \pi_{t+1}=\pi_{t-1}$.

When we present simulated results from these models, we try to pick plausible parameter values. Some of these parameters depend on the time interval. For concreteness, we take the period in the model to equal one quarter. We set $\alpha=.1$ and $\lambda=.25$ (and, thus, $\beta=.0083$ ). This value of $\lambda$ means that firms on average make adjustments once a year. The small value of $\alpha$ means that a firm's desired relative price is not very sensitive to macroeconomic conditions. Note that the firm's desired nominal price can now be written as

$$
p_{t}^{*}=(1-\alpha) p_{t}+\alpha m_{t} .
$$

If $\alpha$ is small, then each firm gives more weight to what other firms are charging than to the level of aggregate demand. ${ }^{3}$

We now consider three hypothetical policy experiments. In each experiment, we posit a path for aggregate demand $m$. We then derive the path for output and inflation generated by the sticky-information model and compare it with the paths generated by the two benchmark models. The details of the solution are presented in the Appendix. Here we discuss the dynamic paths followed by output and inflation.

\section{II.A. Experiment 1: A Drop in the Level of Aggregate Demand}

The first experiment we consider is a sudden and permanent drop in the level of aggregate demand. The demand variable $m_{t}$ is constant and then, at time zero, unexpectedly falls by 10 percent and remains at this new level.

The top graph in Figure I shows the path of output predicted by each of the three models. In all three models, the fall in demand causes a recession, which gradually dissipates over time.

3. In the backward-looking model, the parameter $\beta$ determines the cost of disinflation. According to this model, if output falls 1 percent below potential for one quarter, then the inflation rate falls by $\beta$ if measured at a quarterly rate, or $4 \beta$ if annualized. If output falls by 1 percent below potential for one year, then the annualized inflation rate falls by $16 \beta$. Thus, the sacrifice ratio- the output loss associated with reducing inflation by one percentage point-is $1 /(16 \beta)$. Our parameters put the sacrifice ratio at 7.5. For comparison, Okun's [1978] classic study estimated the sacrifice ratio to be between 6 and 18 percent; Gordon [1997, footnote 8] puts it at 6.4. Thus, our backward-looking model is in the ballpark of similar models used in the previous literature. 


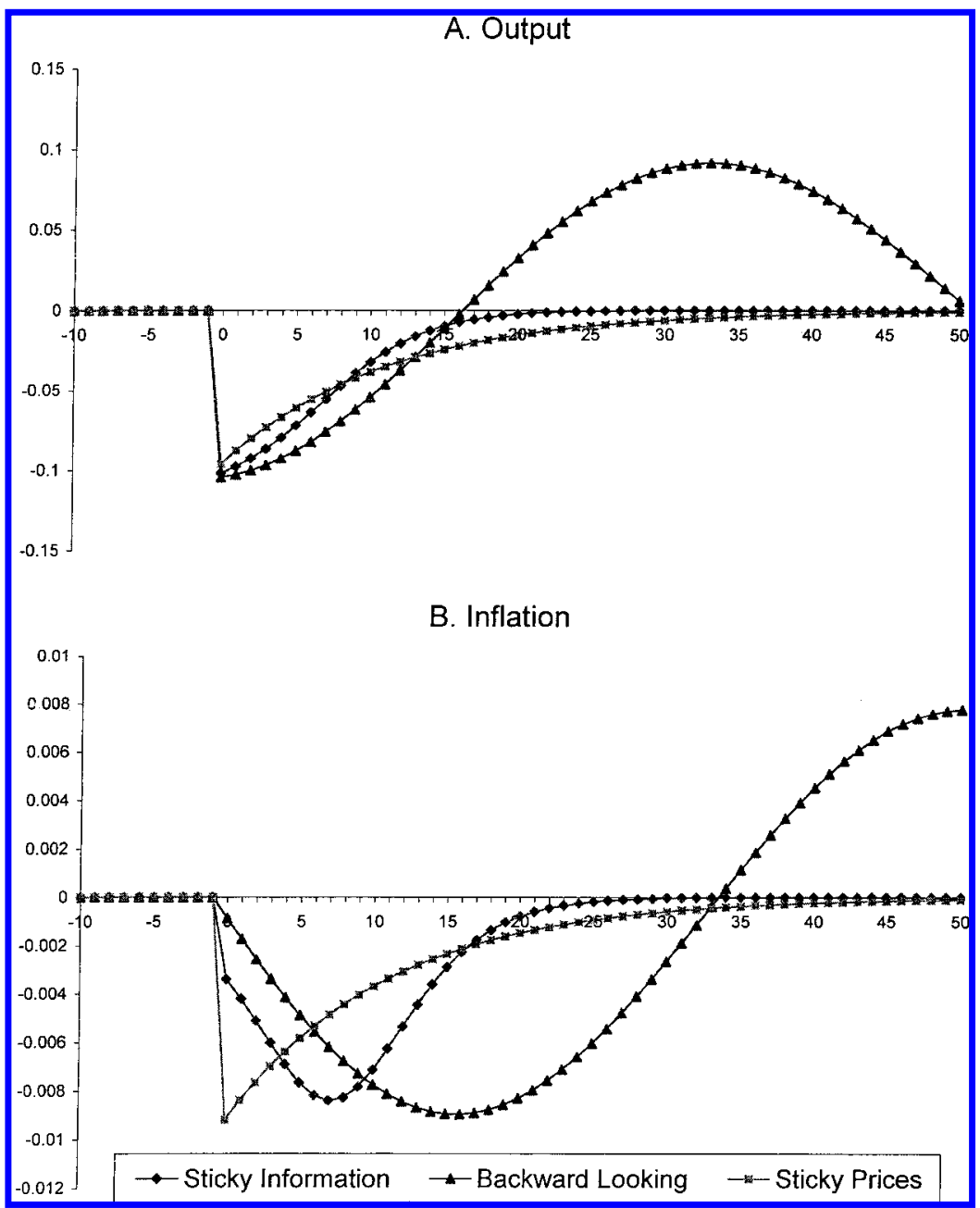

FIGURE I

Dynamic Paths after a 10 Percent Fall in the Level of Aggregate Demand at Time 0

The impact of the fall in demand on output is close to zero at sixteen quarters. The backward-looking model generates an oscillatory pattern, whereas the other two models yield monotonic paths. Otherwise, the models seem to yield similar results.

Differences among the models become more apparent, however, when we examine the response of inflation in the bottom of Figure I. In the sticky-price model, the greatest impact of the fall 
in demand on inflation occurs immediately. The other two models show a more gradual response. In the sticky-information model, the maximum impact of the fall in demand on inflation occurs at seven quarters. Inflation could well be described as inertial.

The inertial behavior of inflation in the sticky-information model requires the parameter $\alpha$ to be less than one. Recall that the firm's desired price is

$$
p_{t}^{*}=(1-\alpha) p_{t}+\alpha m_{t} .
$$

If $\alpha=1$, then the desired price moves only with the money supply. In this case, firms adjust their prices immediately upon learning of the change in policy; as a result, inflation responds quickly (much as it does in the sticky-price model). By contrast, if $\alpha<1$, then firms also care about the overall price level and, therefore, need to consider what information other firms have. For small $\alpha$, even an informed firm will not adjust its price much to the change in aggregate demand until many other firms have also learned of it. A small value of $\alpha$ can be interpreted as a high degree of real rigidity (to use the terminology of Ball and Romer [1990]) or a high degree of strategic complementarity (to use the terminology of Cooper and John [1988]). In the sticky-information model, this real rigidity (or strategic complementarity) is a source of inflation inertia.

\section{II.B. Experiment 2: A Sudden Disinflation}

The second experiment we consider is a sudden and permanent shift in the rate of demand growth. The demand variable $m_{t}$ is assumed to grow at 10 percent per year ( 2.5 percent per period) until time zero. In period 0 , the central bank sets $m_{t}$ the same as it was in the previous period and, at the same time, announces that $m_{t}$ will thereafter remain constant. Figure II shows the path of output and inflation predicted by the three models.

According to the sticky-price model, inflation falls immediately to the lower level. Price setters, realizing that disinflation is underway, immediately respond by making smaller price adjustments. Prices are sticky in the sticky-price model, but inflation exhibits no inertia. The response of output, of course, is the other side of the coin. Because inflation responds instantly to the fall in money growth, output does not change. As in Phelps [1978], disinflation is costless.

By contrast, the sticky-information model predicts a gradual reduction in inflation. Even after the disinflationary policy is in 


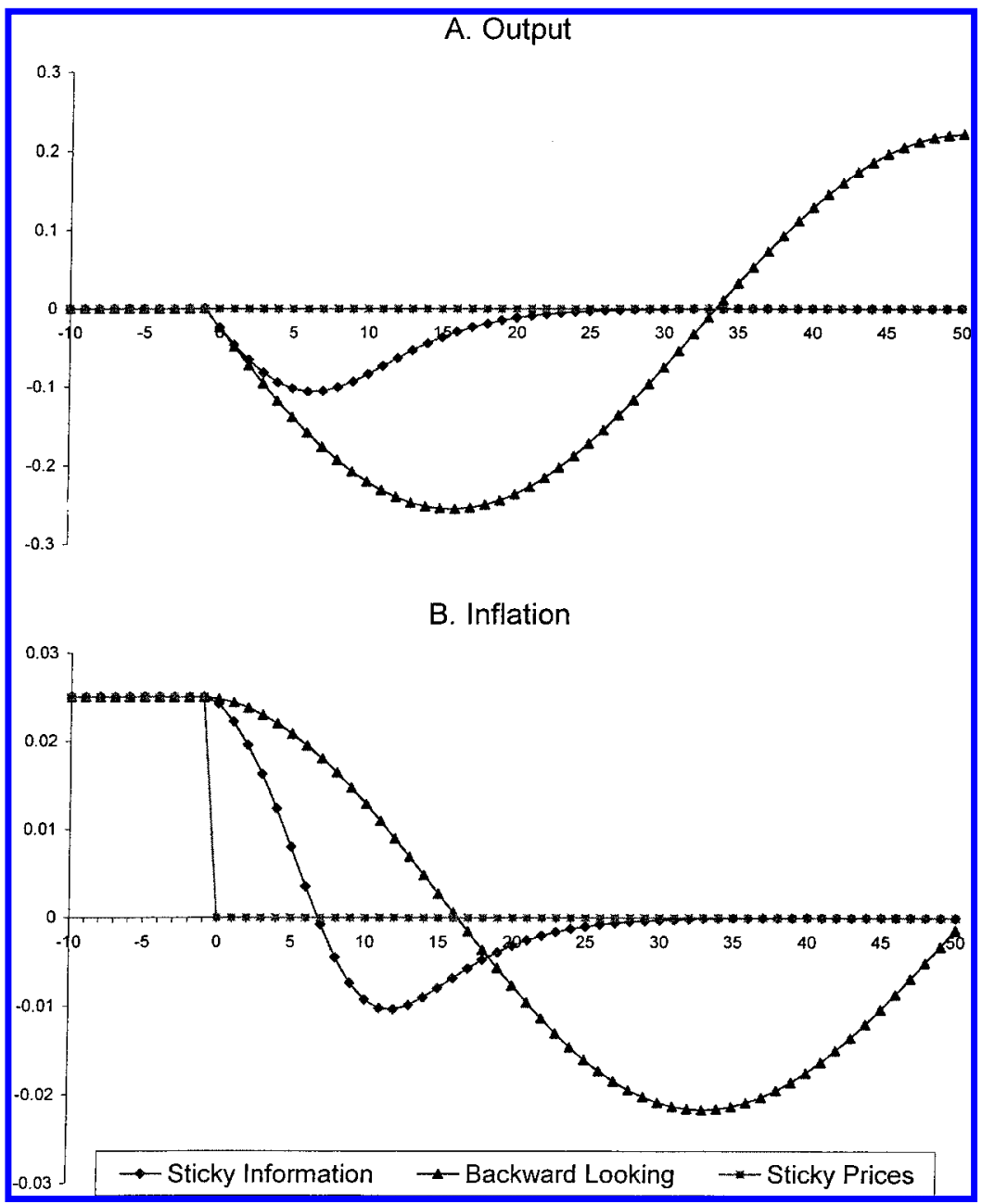

FIGURE II

Dynamic Paths Given an Unanticipated Fall in the Growth Rate of Aggregate Demand at Date 0

place, most price setters are still marking up prices based on old decisions and outdated information. As a result of this inertial behavior, inflation is little changed one or two quarters after the disinflation has begun. With a constant money supply and rising prices, the economy experiences a recession, which reaches a trough six quarters after the policy change. Output then gradu- 
ally recovers and is almost back to normal after twenty quarters. These results seem roughly in line with what happens when nations experience disinflation. ${ }^{4}$

\section{II.C. Experiment 3: An Anticipated Disinflation}

Now suppose that the disinflation in our previous experiment is announced and credible two years (eight periods) in advance. Let us consider how this anticipated disinflation affects the path of output and inflation.

Figure III shows output and inflation according to the three models. The predictions for the backward-looking model are exactly the same as in Experiment 2: the assumption of adaptive expectations prevents the announcement from having any effect. But the results are different in the other two models, which posit rational expectations.

In the sticky-price model, the announced disinflation causes a boom. As Ball [1994a] emphasizes, inflation in this model moves in anticipation of demand. When price setters anticipate a slowdown in money growth, inflation falls immediately. This fall in inflation, together with continued increases in the money supply, leads to rising real money balances and higher output.

By contrast, the sticky-information model does not produce booms in response to anticipated disinflations. In this model, there is no change in output or inflation until the disinflationary policy of slower money growth begins. Then, the disinflation causes a recession.

It would be wrong to conclude, however, that the announcement has no effect in the sticky-information model. Because of the announcement, many price setters have already adjusted their plans in response to the disinflationary policy when it begins. As a result, an announced slowdown in money growth leads to a quicker inflation response and a smaller output loss than does a sudden slowdown in money growth. For these parameters a disinflation announced and fully credible eight quarters in advance has a cumulative cost that is about one-fifth the size of the surprise disinflation.

In a way, the sticky-information model combines elements of

4. Ball [1994b] examines disinflation for a number of countries. For the nine countries for which quarterly data are available, he identifies 28 periods of disinflation. In 27 of these cases, the decline in inflation is associated with a fall in output below its trend level. This finding is related to the acceleration phenomenon we document and discuss below. 


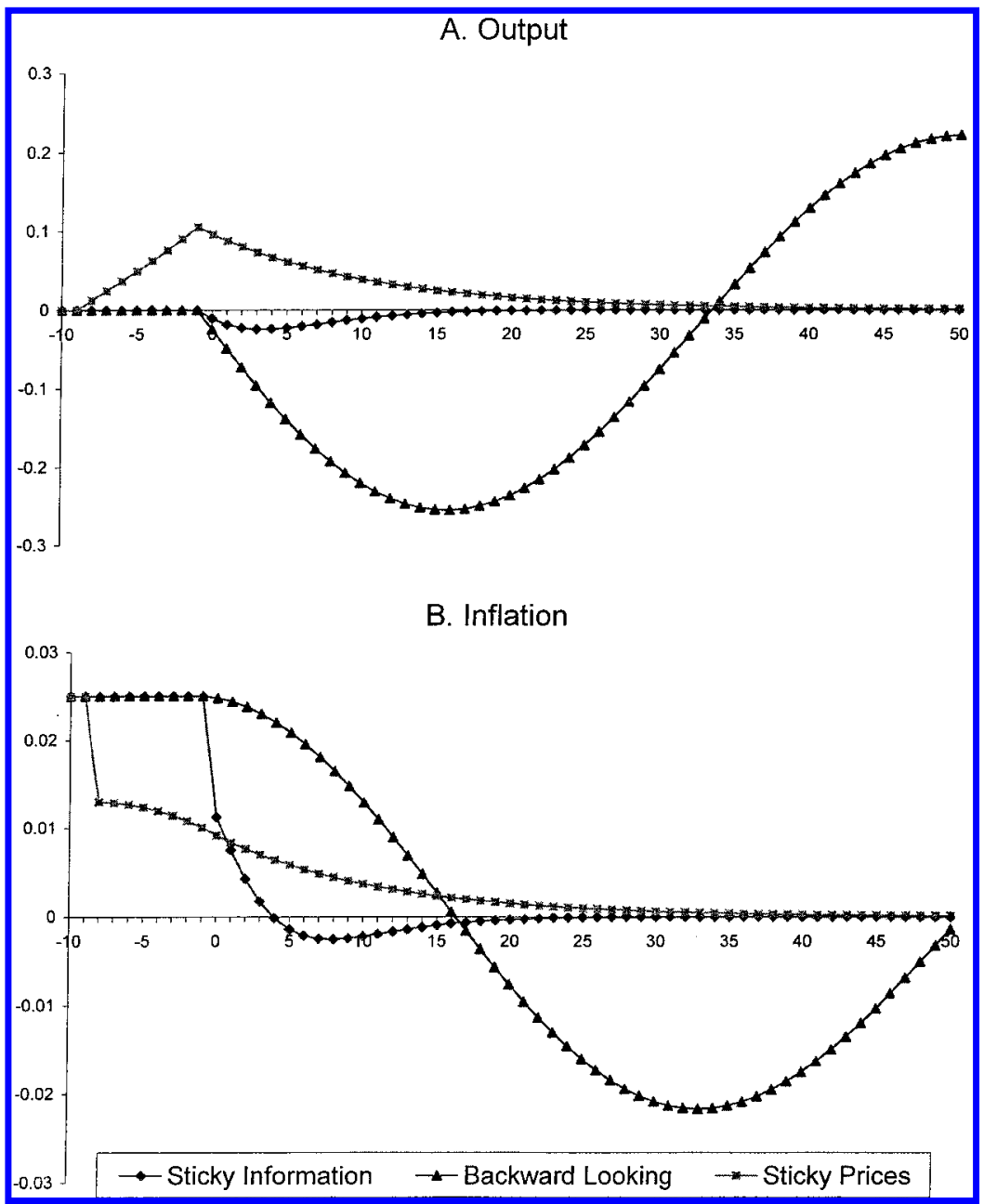

FIGURE III

Dynamic Paths Given an Announcement at Date -8 of a Fall in the Growth Rate of Aggregate Demand at Date 0

the other two models. Like the backward-looking model (but unlike the sticky-price model), disinflations consistently cause recessions rather than booms. Like the sticky-price model (but unlike the backward-looking model), expectations, announcements, and credibility matter for the path of inflation and output. These features of the sticky-information model seem consistent with how central bankers view their influence on the economy. 


\section{The Response to Realistic Monetary Shocks}

So far, we have compared how output and inflation respond to hypothetical paths for aggregate demand. We now take a step toward greater realism. In particular, we assume a plausible stochastic process for the money supply and then examine the implied processes of output and inflation. As Christiano, Eichenbaum, and Evans [1999] discuss, economists have a good sense of the dynamic effects of monetary policy shocks. One way to gauge a model's empirical validity is to see whether it can generate plausible responses to such shocks.

\section{III.A. The Stochastic Process for the Money Supply}

We model the growth in the demand variable $m$ as following a first-order autoregressive process: $\Delta m_{t}=\rho \Delta m_{t-1}+\epsilon_{t}$. In this environment, the price level is nonstationary, but the inflation rate is stationary.

To calibrate $\rho$, we looked at quarterly U. S. data from 1960 to 1999. The variable $m$ can be interpreted as a measure of money supply, such as M1 or M2, or more broadly as a measure of aggregate demand, such as nominal GDP. The first autocorrelations for these time series are 0.57 for M1 growth, 0.63 for M2 growth, and 0.32 for nominal GDP growth. Based on these numbers, we set $\rho=0.5$. The standard deviation of the residual is 0.009 for M1, 0.006 for M2, and 0.008 for nominal GDP, so we assume a standard deviation of 0.007 (although this choice affects only the scale and not the shape of the dynamic paths).

The positive value of $\rho$ means that a monetary shock builds over time. That is, a positive shock $\epsilon$ causes $m$ to jump up and then to continue to rise. With $\rho=0.5$, the level of $m$ eventually asymptotes to a plateau that is twice as high as the initial shock. This pattern for monetary shocks is broadly consistent with that found in empirical studies. ${ }^{5}$

\section{III.B. Impulse Responses}

Figure IV show the response of output and inflation to a one-standard-deviation contractionary monetary policy shock. In all three models, output exhibits a hump-shaped response. The impact on output at first increases because demand is building

5. For example, Christiano, Eichenbaum, and Evans [1998] conclude that an $\mathrm{AR}(1)$ process offers a good description of monetary policy shocks when using M2 as the measure of money. 


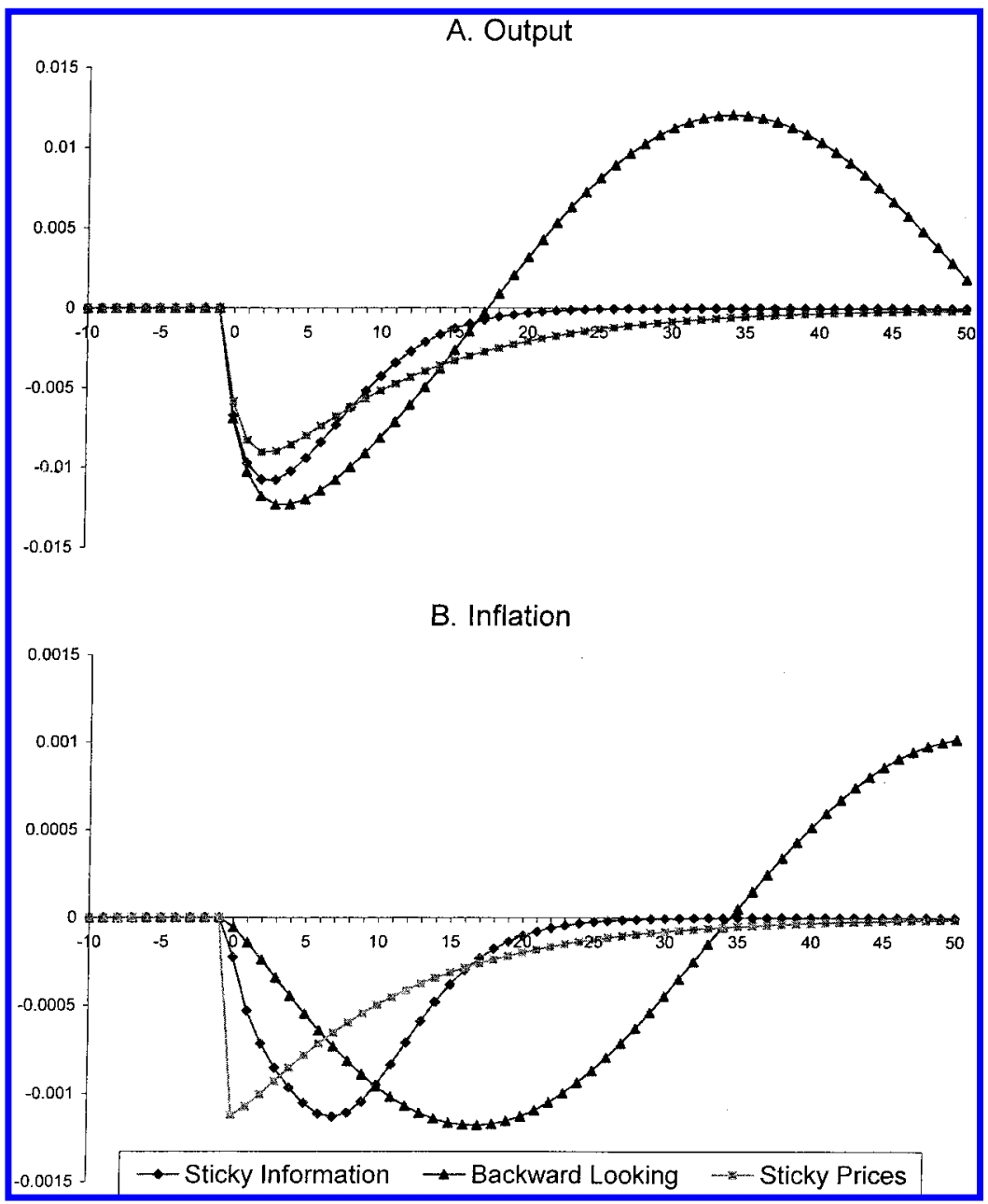

Figure IV

Dynamic Paths after a Negative One Standard Deviation $(-0.007)$ Shock to the AR(1) Aggregate Demand

over time. It eventually decays because prices adjust. The backward-looking model yields oscillatory dynamics, whereas the other two models yield a monotonic recovery from the recession.

The impulse responses for inflation to the monetary shock show the differences between the sticky-price and sticky-information models. In the sticky-price model, inflation responds quickly 
to a monetary policy shock. In fact, the largest impact on inflation occurs immediately. By contrast, the sticky-information model displays some of the inflation inertia that is built into the backward-looking model. For these parameters, a monetary policy shock in the sticky-information model has its maximum impact on inflation after seven quarters.

The impulse response function for the sticky-information model is far more consistent with conventional views about the effects of monetary policy. Economists such as Friedman [1948] have emphasized the long lags inherent in macroeconomic policy. In particular, a long lag between monetary policy actions and inflation is accepted by most central bankers and confirmed by most econometric studies. ${ }^{6}$ Figure IV shows that the sticky-information model can explain a long lag between monetary policy shocks and inflation, whereas the standard sticky-price model cannot.

\section{III.C. Inflation Persistence}

Fuhrer and Moore [1995] argue that the standard stickyprice model "is incapable of imparting the persistence to inflation that we find in the data" [p. 127]. In the model, they claim, "the autocorrelation function of inflation ... will die out very rapidly" [p. 152]. This contradicts the empirical autocorrelations of inflation, which decay slowly.

Motivated by these arguments, we calculated the implied autocorrelations of inflation in our three models. We maintain the empirically realistic process for money growth used above: $\Delta m_{t}=$ $0.5 \Delta m_{t-1}+\epsilon_{t}$. Table I presents the first eight autocorrelations of inflation implied by the models, as well as the actual autocorrelations of inflation using the GDP deflator, the consumer price index, and the core CPI. (The core CPI is the index excluding food and energy.) Notice that inflation is highly autocorrelated in all three models. That is, given the empirically realistic process for the money supply, all the models deliver plausible persistence in inflation.

In the end, we agree with Taylor [1999, p. 1040], who responds to Fuhrer and Moore by observing that "inflation persistence could be due to serial correlation of money." This is why all three models deliver high autocorrelations in Table I. Yet we also agree with Fuhrer and Moore's deeper point: the standard sticky-

6. See, for example, Bernanke and Gertler [1995] or Christiano, Eichenbaum, and Evans [1999]. 
TABLE I

Autocorrelations for Inflation: Predicted and Actual

\begin{tabular}{ccccccc}
\hline \hline & $\begin{array}{c}\text { Sticky- } \\
\text { information } \\
\text { model }\end{array}$ & $\begin{array}{c}\text { Sticky- } \\
\text { price } \\
\text { model }\end{array}$ & $\begin{array}{c}\text { Backward- } \\
\text { looking } \\
\text { model }\end{array}$ & $\begin{array}{c}\text { Actual: } \\
\text { GDP } \\
\text { deflator }\end{array}$ & $\begin{array}{c}\text { Actual: } \\
\text { CPI }\end{array}$ & $\begin{array}{c}\text { Actual: } \\
\text { core } \\
\text { CPI }\end{array}$ \\
\hline 1 & 0.99 & 0.92 & 0.99 & 0.89 & 0.76 & 0.76 \\
2 & 0.95 & 0.85 & 0.98 & 0.83 & 0.72 & 0.71 \\
3 & 0.89 & 0.78 & 0.96 & 0.81 & 0.73 & 0.69 \\
4 & 0.82 & 0.71 & 0.94 & 0.78 & 0.62 & 0.59 \\
5 & 0.74 & 0.65 & 0.90 & 0.71 & 0.57 & 0.55 \\
6 & 0.66 & 0.59 & 0.86 & 0.65 & 0.51 & 0.54 \\
7 & 0.57 & 0.54 & 0.81 & 0.61 & 0.44 & 0.46 \\
8 & 0.48 & 0.50 & 0.75 & 0.58 & 0.33 & 0.38 \\
\hline \hline
\end{tabular}

The first three columns of this table show the autocorrelations of inflation predicted by three models. These calculations assume that money growth follows the process $\Delta m_{t}=0.5 \Delta m_{t-1}+\epsilon_{t}$. The model parameters are set to $\alpha=.1$ and $\lambda=.25$. The last three columns show the actual autocorrelations of quarterly inflation rates.

price model does not deliver empirically reasonable dynamics for inflation and output. The key empirical fact that is hard to match, however, is not the high autocorrelations of inflation, but the delayed response of inflation to monetary policy shocks. ${ }^{7}$

\section{The Acceleration Phenomenon}

When economists want to document the Phillips curve relationship in U. S. data from the last few decades of the twentieth century, a common approach is to look at a scatterplot of the change in inflation and some level of economic activity, such as unemployment or detrended output. This scatterplot shows that when economic activity is vigorous, as represented by low unemployment or high output, inflation tends to rise. We call this correlation the acceleration phenomenon. ${ }^{8}$

Panel A of Table II demonstrates the acceleration phenomenon using U. S. quarterly data from 1960 to 1999. For these

7. Fuhrer and Moore also emphasize the persistence of inflation in response to "inflation shocks," which could be interpreted as supply shocks. The model we have developed here cannot address this issue, because there are no supply shocks. In Mankiw and Reis [2001] we take a step toward remedying this omission.

8. For some examples of economists using such a scatterplot to demonstrate the acceleration phenomenon, see Abel and Bernanke [1998, p. 457], Blanchard [2000, p. 155], Dornbusch, Fischer and Startz [2001, p. 109], Hall and Taylor [1993, p. 217], and Stock and Watson [1999, p. 48]. 
TABLE II

The Acceleration Phenomenon

\begin{tabular}{lcc}
\hline \hline & $\operatorname{corr}\left(y_{t}, \pi_{t+2}-\pi_{t-2}\right)$ & $\operatorname{corr}\left(y_{t}, \pi_{t+4}-\pi_{t-4}\right)$ \\
\hline A. Actual & & \\
\hline GDP deflator & .48 & .60 \\
CPI & .38 & .46 \\
$\quad$ Core CPI & .46 & .51 \\
B. Predicted & .99 & .99 \\
$\quad$ Backward-looking model & -.13 & -.11 \\
Sticky-price model & .43 & .40 \\
$\quad$ Sticky-information model & & \\
\hline \hline
\end{tabular}

Panel A shows the correlation between output and the change in inflation in U. S. quarterly data from 1960 to 1999. The variable $y$ is measured as log real GDP detrended with the Hodrick-Prescott filter. Panel $\mathrm{B}$ shows the correlation between output and the change in inflation predicted by three models. These correlations assume that money growth follows the process: $\Delta m_{t}=0.5 \Delta m_{t-1}+\epsilon_{t}$. The model parameters are set to $\alpha=.1$ and $\lambda=.25$.

calculations, output $y_{t}$ is the deviation of log real GDP from trend, where trend is calculated using the Hodrick-Prescott filter. We use three measures of inflation: the GDP deflator, the CPI, and the core CPI. We use two timing conventions: we correlate $y_{t}$ with $\pi_{t+2}-\pi_{t-2}$, the one-year change in inflation centered around the observation date, and with $\pi_{t+4}-\pi_{t-4}$, the two-year change in inflation. All six correlations are positive and statistically significant. In U. S. data, high output is associated with rising inflation.

We now consider whether the models can generate the positive correlation between output and the change in inflation. We assume the same stochastic process for the money supply as in the previous section $\left(\Delta m_{t}=0.5 \Delta m_{t-1}+\epsilon_{t}\right)$ and the same parameters $(\alpha=.1$ and $\lambda=.25)$. Then, as explained in the Appendix, we compute the population correlation between output and the change in inflation.

Panel B of Table II shows the correlation predicted by the models. Not surprisingly, the backward-looking model predicts a high correlation. Because $\pi_{t}-\pi_{t-1}=\beta y_{t}$ in this model, the correlation is perfect for the one-period change in inflation and only slightly lower for longer changes. In essence, the model builds in the acceleration phenomenon through the assumption of adaptive expectations. This is hardly a major intellectual victory: the appeal of the backward-looking model comes not from its theoretical underpinnings but from its ability to fit this phenomenon. 
TABLE III

The Acceleration Phenomenon: Sensitivity Analysis

\begin{tabular}{|c|c|c|c|c|}
\hline \multicolumn{5}{|c|}{ A. Sticky-price model } \\
\hline & $\frac{\alpha}{\alpha}=.05$ & $\alpha=.1$ & $\alpha=.5$ & $\alpha=1.0$ \\
\hline$\lambda=.1$ & -0.08 & -0.09 & -0.12 & -0.13 \\
\hline$\lambda=.25$ & -0.12 & -0.13 & -0.15 & -0.15 \\
\hline$\lambda=.5$ & -0.15 & -0.15 & -0.13 & -0.11 \\
\hline \multicolumn{5}{|c|}{ B. Sticky-information model } \\
\hline & $\alpha=.05$ & $\alpha=.1$ & $\alpha=.5$ & $\alpha=1.0$ \\
\hline$\lambda=.1$ & 0.49 & 0.39 & 0.05 & -0.04 \\
\hline$\lambda=.25$ & 0.51 & 0.43 & 0.12 & 0.02 \\
\hline$\lambda=.5$ & 0.52 & 0.44 & 0.21 & 0.13 \\
\hline
\end{tabular}

This table shows the correlation between output $y_{t}$ and the change in inflation $\pi_{t+2}-\pi_{t-2}$. These correlations assume money growth follows the process: $\Delta m_{t}=0.5 \Delta m_{t-1}+\epsilon_{t}$.

We next look at the two models with better foundations. Table II shows that the sticky-price model yields no association between output and the change in inflation. For the one-year change, the correlation between these variables is -0.13 , which is small and the wrong sign. By contrast, the sticky-information model yields a strong, positive association. According to this model, the correlation between output and the change in inflation is $0.43 .^{9}$

To understand these results, recall the impulse response functions. In the sticky-price model, when the economy experiences a contractionary monetary shock, output falls for a while. Inflation falls immediately, and then starts rising. Thus, low output coincides with falling inflation at first, but then coincides with rising inflation for a long period. This generates the small, negative correlation.

By contrast, in the sticky-information model, inflation adjusts slowly to a monetary shock. When a contractionary shock lowers output, it also leads to a prolonged period of falling inflation. This generates the positive correlation between output and the change in inflation.

Table III presents a sensitivity analysis of this correlation to alternative parameter values. Panel A of the table shows the

9. Our finding that the calibrated sticky-price model predicts a negative correlation between $y$ and $\Delta \pi$ (in contrast to the positive correlation in the data) is related to Gali and Gertler's finding [1999] that econometric estimation of this model yields a coefficient on output of the wrong sign. Gali and Gertler's proposed fix to the sticky-price model, however, differs substantially from the stickyinformation model proposed here. 
correlation produced by the sticky-price model for different parameter values. Panel $\mathrm{B}$ shows the correlation produced by the sticky-information model. The sticky-price model consistently generates a small correlation of the wrong sign, whereas the sticky-information model typically yields a positive correlation between output and the change in inflation. ${ }^{10}$

\section{Responses to Skeptics}

A skeptic of the sticky-information model might naturally ask two questions. What is the evidence for the model? What are the model's microeconomic foundations? At this point, we cannot give definitive answers, but we can offer some suggestive insights.

\section{V.A. Evidence}

We were motivated to explore the sticky-information model by a set of empirical anomalies. As we have discussed, the canonical sticky-price model of inflation-output dynamics cannot be reconciled with the conventional wisdom about the effects of monetary policy, whereas the sticky-information model is consistent with the conventional wisdom. This fact is itself evidence in favor of this model compared with the leading alternative.

Our skeptic might say that the backward-looking model, with its assumption of adaptive expectations, can also be reconciled with the conventional wisdom. Or he might claim that the sticky-information model is little more than a revival of adaptive expectations. There are, however, at least two key differences between the stickyinformation model and the backward-looking model, and they argue in favor of the sticky-information model. Both of these differences arise from the fact that agents in the sticky-information model form expectations rationally, even though they do not do so often.

One difference relates to changes in regime. As Barsky [1987] and Ball [2000] point out, inflation has been close to a random walk in the period since World War II, whereas before World War I, when the gold standard was in effect, it was close to white noise. The sticky-information model predicts that the reduced-form

10. These simulated correlations are computed under the assumption that all fluctuations are due to demand shocks. If we were to append supply shocks to this model, the predicted correlations would likely be driven down, because such shocks push inflation and output in opposite directions. Thus, supply shocks would make it even harder for the sticky-price model to match the positive correlation in the data. 
Phillips curve should shift in response to this regime change. In the recent period, expected inflation should roughly equal past inflation, and output should be related to changes in inflation; that is, the data should conform with the accelerationist Phillips curve. In the early period, expected inflation should be roughly constant, and output should be related to the level of inflation; that is, the data should conform with the classic Phillips curve. Ball [2000] reports that these two predictions hold true in the data, which is inconsistent with the backward-looking model strictly construed as a structural relationship. ${ }^{11}$

A second difference between the sticky-information model and the backward-looking model concerns the role of credibility. In the model with backward-looking expectations, credibility in monetary policy has no role. By contrast, in the sticky-information model, credibility can reduce the costs of disinflation. Most central bankers believe that credibility is important, but this belief is hard to confirm empirically. One intriguing study is that of Boschen and Weise [2001], which examines 72 disinflationary episodes from 19 OECD countries. This study measures credibility as the probability of success conditional on economic and political variables known at the start of the disinflation. They report that credibility lowers the output cost of reducing inflation. This finding is consistent with the sticky-information model but not with the backward-looking model.

Our skeptic might also ask for evidence on whether price setters actually respond to information slowly. One piece of evidence comes from Zbaracki et al. [2000], a study of the costs associated with changing prices at a large manufacturing firm. In this extensive case study, the authors find that only a small percentage of these costs are the physical costs of printing and distributing price lists. Far more important are the "managerial and customer costs," which include the costs of informationgathering, decision-making, negotiation, and communication. Whether our sticky-information model captures the effects of such costs is an open question, but this microeconomic evidence suggest that macroeconomists need to think broadly about the frictions that impede price adjustment.

11. Although the sticky-information model is consistent with Ball's findings, other models may be as well. Ball proposes his own explanation: agents are assumed to follow optimal univariate forecasts but to ignore information in other variables. In Ball's theory, the optimal univariate forecasting rule changes when the monetary regime changes. 
In a recent paper Carroll [2001] reports some direct evidence on the slow dissemination of information about inflation. Motivated in part by our sticky-information model, Carroll compares the inflation expectations from surveys of two groups: professional forecasters and the general public. Not surprisingly, he finds that the professional forecasters are better at forecasting inflation than the general public is. More important, he finds that the general public's expectations respond to the professionals' expectations with a lag. Based on the assumption that professionals do not suffer from sticky information, he estimates a parameter similar to our $\lambda$ that measures how quickly the public's expectations catch up. Remarkably, the estimated value of $\lambda$ is almost exactly the 0.25 that we assumed above. ${ }^{12}$

Carroll [2001] also reports two related pieces of evidence that cannot be explained with the sticky-information model as presented here. He finds that the professional's and the public's expectations are closer on average when there are more news stories about inflation. In addition, when there are more news stories about inflation, the public's expectations adjust more rapidly to the professional's expectations. Thus, although Carroll's study is consistent with the hypothesis that the public's inflation expectations adjust slowly, it suggests that the rate of information acquisition $\lambda$ is not constant over time.

\section{V.B. Microfoundations}

The starting point of this paper is the premise that some price setters respond to information about monetary policy with a lag. This hypothesis raises many questions. Why, exactly, do people set prices based on outdated information? What set of constraints on the process of decision-making leads to this outcome? How can economists model these imperfections in human understanding?

One approach to answering these questions is to use the tools of information theory, as exposited, for instance, in the textbook by Cover and Thomas [1991]. Drawing on these tools, Sims [2001] suggests modeling humans as having a limited channel for absorbing information. Woodford [2001] uses this idea to build a model of inflation-output dynamics. In his model, because price setters learn about monetary policy through a limited-information channel, it is as if they observe monetary policy with a

12. In Mankiw and Reis [2001] we econometrically implement a model closely related to the one developed here. We also find that $\lambda=0.25$ fits the data well. 
random error and have to solve a signal-extraction problem along the lines of Lucas [1973].

As Woodford [2001] notes, his noisy-information model is proposed in the same spirit as the sticky-information model explored in this paper. The difference between the models is how information arrives. In Woodford's model, price setters get a noisy signal about monetary policy in every period. In our model, price setters obtain perfect information about monetary policy with probability $\lambda$ in every period. This difference in information arrival leads to some differences in the dynamic response to monetary policy. ${ }^{13}$

Information theory, however, may not be the best approach to microfoundations. For most people, it is easy to find out what the monetary authority is doing, but it is much harder to figure out what it means. As Begg and Imperato [2001] emphasize, the real cost is the cost of thinking. One interpretation of the sticky-information model is that because thinking is costly, people do it only once in a while and, at other times, continue with outdated plans.

At best, this time-contingent approach to thinking is only an approximation. How much a person thinks about an issue depends on the benefit of doing so. Most people spend little time thinking about monetary policy, but circumstances can affect the allocation of their mental resources. This might explain Carroll's finding that the public's expectations of inflation adjust more rapidly when there are more news stories about inflation. Similarly, the ends of hyperinflations (as studied by Sargent [1982]) may be different than more typical disinflations (as studied by Ball [1994b]) because the major institutional reforms that end hyperinflations are exceptionally newsworthy events.

In the end, microfoundations for the Phillips curve may require a better understanding of bounded rationality. But until those foundations are established, the sticky-information model as described here may offer a useful tool for the study of inflationoutput dynamics.

\section{ConcLusion}

This paper has explored a dynamic model of price adjustment. In particular, we have proposed a model to replace the

13. Our model, like Woodford's, starts by simply assuming the nature of the information flow. Alternatively, one could start by assuming some cost of using an information channel and then derive the optimal flow of information. See Moscarini [2001] for an exploration of this issue in a different context. 
widely used "new Keynesian Phillips curve." In this model, prices are always changing, but decision-makers are slow to update their pricing strategies in response to new information.

Although the choice between the sticky-information model and the standard sticky-price model is ultimately an empirical issue, three of our findings suggest that the sticky-information model is more consistent with accepted views of how monetary policy works. First, in the sticky-information model, disinflations are always contractionary (although announced disinflations are less costly than surprise ones). Second, in the stickyinformation model, monetary shocks have their maximum effect on inflation with a substantial delay. Third, the stickyinformation model can explain the acceleration phenomenon that vigorous economic activity is positively correlated with rising inflation.

The dynamic patterns implied by the sticky-information model resemble those from the Fischer [1977] contracting model, although long-term contracts have no role. In both models, past expectations of the current price level play a central role in inflation dynamics. In a sense, the slow dissemination of information in our model yields a nominal rigidity similar to the one Fischer assumed in his contracts.

Critics of the Fischer contracting model (e.g., Barro [1977]) have noted that it is hard to rationalize signing such contracts ex ante or enforcing them ex post in light of the obvious inefficiencies they cause. Such critiques do not apply to the model proposed here. The assumption of slow information diffusion, perhaps due to costs of acquiring or acting on new information, leaves no apparent, unrealized gains from trade. Thus, sticky information offers a more compelling rationale for this type of nominal rigidity.

Moving the theory of price adjustment away from sticky prices toward sticky information may seem like a radical suggestion, but we temper it with an important observation: many lessons from the "new Keynesian" literature on price adjustment apply as well to our sticky-information model as they do to the standard sticky-price model.

An early lesson about price adjustment by firms with some degree of monopoly power is that the private losses from sticky prices are only second order, even if the social losses are first order [Mankiw 1985; Akerlof and Yellen 1985]. Thus, if firms face small costs of price adjustment or are only near rational, they may choose to maintain sticky prices, even if the macroeconomic 
effect of doing so is significant. When we move from sticky prices to sticky information, this lesson applies in somewhat modified form. If there are small costs of acquiring information or recomputing optimal plans, firms may choose not to update their pricing strategies. The private loss from maintaining old decisions, like the cost of maintaining old prices, is second order.

Another lesson from the literature on price adjustment is that real rigidities amplify monetary nonneutralities [Ball and Romer 1990]. Real rigidity is defined as a lack of sensitivity of desired relative prices to macroeconomic conditions. Here, this translates into a small value of the parameter $\alpha$. Real rigidities also play a role in our sticky-information model. Price setters who are updating their decisions are aware that other price setters are not, and this knowledge limits the size of their adjustments, especially when $\alpha$ is small. As a result, real rigidity tends to exacerbate the effects of monetary policy.

An advantage of sticky-information over sticky-price models is that they more naturally justify the widely assumed time-contingent adjustment process. If firms have sticky prices because of menu costs but are always collecting information and optimizing in response to that information, then it is natural to assume state-contingent adjustment. Dynamic models of state-contingent adjustment, however, often yield empirically implausible results; Caplin and Spulber's [1987] conclusion of monetary neutrality is a famous example. By contrast, if firms face costs of collecting information and choosing optimal plans, then it is more natural to assume that their adjustment process is time-contingent. Price setters cannot react between scheduled adjustments, because they are not collecting the information and performing the calculations necessary for that purpose.

Yet we must admit that information processing is more complex than the time-contingent adjustment assumed here. Models of bounded rationality are notoriously difficult, but it seems clear that when circumstances change in large and obvious ways, people alter the mental resources they devote to learning and thinking about the new aspects of the world. Developing better models of how quickly people incorporate information about monetary policy into their plans, and why their response is faster at some times than at others, may prove a fruitful avenue for future research on inflation-output dynamics. 
Appendix: Details of Solutions

This Appendix explains the solutions of the three models presented in the text.

\section{A. The Derivation of the Sticky-Price Phillips Curve}

From the equations for the adjustment price $x_{t}$ and the price level $p_{t}$, breaking the sum and using the law of iterated expectations, we obtain

$$
\begin{aligned}
& x_{t}=\lambda p_{t}^{*}+(1-\lambda) E_{t} x_{t+1}, \\
& p_{t}=\lambda x_{t}+(1-\lambda) p_{t-1} .
\end{aligned}
$$

But then solving for $x_{t}$ in (A2) and replacing in (A1) for $x_{t}$ and $x_{t+1}$, together with the definition of $p_{t}^{*}=p_{t}+\alpha y_{t}$, yields the desired expression for inflation presented in the text.

B. The Derivation of the Sticky-Information Phillips Curve

Begin with the equation for the price level derived in the text:

$$
p_{t}=\lambda \sum_{j=0}^{\infty}(1-\lambda)^{j} E_{t-j}\left(p_{t}+\alpha y_{t}\right) .
$$

By taking out the first term and redefining the summation index, this equation can be written as

$$
p_{t}=\lambda\left(p_{t}+\alpha y_{t}\right)+\lambda \sum_{j=0}^{\infty}(1-\lambda)^{j+1} E_{t-1-j}\left(p_{t}+\alpha y_{t}\right) .
$$

Analogous to equation (A3), the previous period's price level can be written as

$$
p_{t-1}=\lambda \sum_{j=0}^{\infty}(1-\lambda)^{j} E_{t-1-j}\left(p_{t-1}+\alpha y_{t-1}\right) .
$$

Subtracting (A5) from (A4) and rearranging yields the following equation for the inflation rate:

$$
\begin{aligned}
\text { (A6) } \pi_{t}=\lambda\left(p_{t}+\alpha y_{t}\right)+\lambda \sum_{j=0}^{\infty}(1-\lambda)^{j} E_{t-1-j}\left(\pi_{t}+\alpha \Delta y_{t}\right) \\
\\
\quad-\lambda^{2} \sum_{j=0}^{\infty}(1-\lambda)^{j} E_{t-1-j}\left(p_{t}+\alpha y_{t}\right) .
\end{aligned}
$$


Now equation (A4) can be rearranged to show that

$$
p_{t}-\left[\frac{\alpha \lambda}{1-\lambda}\right] y_{t}=\lambda \sum_{j=0}^{\infty}(1-\lambda)^{j} E_{t-1-j}\left(p_{t}+\alpha y_{t}\right) .
$$

We now use equation (A7) to substitute for the last term in equation (A6). After rearranging, we obtain

$$
\pi_{t}=\left[\frac{\alpha \lambda}{1-\lambda}\right] y_{t}+\lambda \sum_{j=0}^{\infty}(1-\lambda)^{j} E_{t-1-j}\left(\pi_{t}+\alpha \Delta y_{t}\right) .
$$

This is the sticky-information Phillips curve presented in the text.

C. The Response of Output and Inflation in the Policy Experiments

The three policy experiments we undertake can be described as follows:

(E1) An unexpected fall in the level of aggregate demand by 10 percent at date 0 . Thus, $m_{t}=-\log (0.9)$ for $t<0$ and $m_{t}=0$ for $t \geq 0$.

(E2) An unexpected drop in the rate of money growth $\Delta m_{t}$ at date 0 , from 2.5 percent per period to 0 percent. Thus, $m_{t}=0.025(1+t)$ for $t \leq-1, m_{t}=0$ for $t \geq 0$.

(E3) Same as (E2) but announced at date $t=-8$.

We focus on finding solutions for $p_{t}$ as a function of $m_{t}$. The solution for $y_{t}$ then follows from the aggregate demand equation.

For the backward-looking model, the solution follows immediately once the aggregate demand equation is used to substitute out for $y$ :

$$
p_{t}(1+\beta)=2 p_{t-1}-p_{t-2}+\beta m_{t} .
$$

This is a second-order difference equation. The associated roots are $\left[1 \pm(-\beta)^{1 / 2}\right] /(1+\beta)$, which are complex (since $\beta>0$ ), generating the oscillatory behavior.

For the sticky-price model, rewrite the Phillips curve, using the aggregate demand equation, as

$$
E_{t} p_{t+1}-(2+\beta) p_{t}+p_{t-1}=-\beta m_{t} .
$$

This is an expectational difference equation, which can be solved by the methods explained in Sargent [1987]. First, take expectations at $t$ and express all expectations at $t$ variables with an asterisk. Then using the lag operator $L$, such that $L E_{t} p_{t}=$ 
$E_{t} p_{t-1}$ and its inverse, the forward operator, $F=L^{-1}$ such that $F E_{t} p_{t}=E_{t} p_{t+1}$, reexpress (A10) as

$$
\left(F^{2}-(2+\beta) F+1\right) L p_{t}^{*}=-\beta m_{t}^{*} .
$$

The quadratic $\left(x^{2}-(2+\beta) x+1\right)$, has two positive roots: $\theta$ and $1 / \theta$, such that $(1-\theta)^{2} / \theta=\beta$. Pick $\theta$ to correspond to the smaller of the roots. Then (A11) becomes

$$
(1-\theta L) p_{t}^{*}=(1-\theta)^{2}(1-F \theta)^{-1} m_{t}^{*} .
$$

But using the fact that $\theta<1$, the inverse on the right-hand side is well defined and can be expanded. Finally, because $p_{t}$ and $p_{t-1}$ are part of date $t$ information set, we obtain the final solution:

$$
p_{t}=\theta p_{t-1}+(1-\theta)^{2} \sum_{i=0}^{\infty} \theta^{i} E_{t} m_{t+i} .
$$

For the policy experiment E1, up to date $0, p_{t}=m_{t}=-\log$ (0.9). From 0 onwards, $E_{t} m_{t+i}=m_{t+i}=0$, so the price level is given by the recursion $p_{t}=\theta p_{t-1}$ with initial condition $p_{-1}=$ $-\log (0.9)$. For E2, $p_{t}=m_{t}$ until $t=-1$, and after again $p_{t}=$ $\theta p_{t-1}$, but now the initial condition is $p_{-1}=0$. Thus, $p_{t}=0, t \geq$ 0 , and so $y_{t}=0$ at all $t$. For E3, in the period $-8 \leq t \leq-1$, then the terms of the sum in the right-hand side of (A13) are $E_{t} m_{t+i}=$ $0.025(1+t)$ for $-8 \leq t+i \leq-1$ and $E_{t} m_{t+i}=0$ for $t+i \geq$ 0 . After that, for $t \geq 0, p_{t}=\theta p_{t-1}$.

Finally, consider the sticky-information model, as captured by the equation:

$$
p_{t}=\lambda \sum_{j=0}^{\infty}(1-\lambda)^{j} E_{t-j}\left[(1-\alpha) p_{t}+\alpha m_{t}\right] .
$$

The price level at time $t \geq 0$ can then be broken into two components, where the first includes price setters aware of the new path for aggregate demand, and the second those agents who decided on their prices before the change:

$$
\begin{aligned}
p_{t}=\lambda \sum_{j=0}^{t}(1-\lambda)^{j} E_{t-j}\left[(1-\alpha) p_{t}+\alpha m_{t}\right] \\
+\lambda \sum_{j=t+1}^{\infty}(1-\lambda)^{j} E_{t-j}\left[(1-\alpha) p_{t}+\alpha m_{t}\right] .
\end{aligned}
$$


Because the agents represented by the second term are still setting prices based on their old information sets, their expectations are given by $E_{t-j} p_{t}=E_{t-j} m_{t}=-\log (0.9)$. As a result, the second term reduces to $-\log (0.9)(1-\lambda)^{t+1}$. The agents represented by the first term have responded to the new path of aggregate demand, so $E_{t-j} m_{t}=0$, and because there is no further uncertainty, $E_{t-j} p_{t}=p_{t}$. Collecting terms and rearranging, we obtain the solution:

$$
p_{t}=\left[-\log (0.9)(1-\lambda)^{t+1}\right] /\left[1-(1-\alpha)\left(1-(1-\lambda)^{t+1}\right)\right]
$$

This equation gives the solution for the price level in the stickyinformation model under policy experiment E1.

We can find the outcome under policy experiment E2 with similar steps. Under E2, however, $E_{t-j} p_{t}=E_{t-j} m_{t}=0.025(1+$ $t$ ) for $t-j<0$. Thus, the solution is

$$
\text { (A17) } p_{t}=\left[0.025(1+t)(1-\lambda)^{t+1}\right] /\left[1-(1-\alpha)\left(1-(1-\lambda)^{t+1}\right)\right] \text {. }
$$

This equation gives the price level in the sticky-information model under policy experiment E2.

Finally, for E3, for $t<0$, the path is the same as expected by all agents, so $p_{t}=m_{t}=0.025(t+1)$ and $y_{t}=0$. After date 0 , $p_{t}$ is given by (note the limit of the sums)

$$
\begin{aligned}
p_{t}=\lambda \sum_{j=0}^{t+8}(1-\lambda)^{j} E_{t-j}\left[(1-\alpha) p_{t}+\alpha m_{t}\right] \\
+\lambda \sum_{j=t+9}^{\infty}(1-\lambda)^{j} E_{t-j}\left[(1-\alpha) p_{t}+\alpha m_{t}\right] .
\end{aligned}
$$

All else is the same as in E2. The solution follows as

$$
p_{t}=\left[0.025(1+t)(1-\lambda)^{t+9}\right] /\left[1-(1-\alpha)\left(1-(1-\lambda)^{t+9}\right)\right]
$$

This equation gives the path of the price level for the stickyinformation model under policy experiment E3.

\section{Output and Inflation When Money Growth Is AR(1)}

Suppose that $\Delta m_{t}=\rho \Delta m_{t-1}+\epsilon_{t}$, where $\epsilon_{t}$ is white noise and $|\rho|<1$. It will prove convenient to write this in MA( $\infty)$ form:

$$
\Delta m_{t}=\sum_{j=0}^{\infty} \rho^{j} \epsilon_{t-j} \quad \text { or } \quad m_{t}=\sum_{k=0}^{\infty} \sum_{j=0}^{\infty} \rho^{j} \boldsymbol{\epsilon}_{t-j-k} .
$$


Consider first the backward-looking model. First-differencing both sides of (A9), multiplying through by $(1-\rho L)$ and rearranging yields the following $\mathrm{AR}(3)$ for the inflation rate:

$$
\text { (A21) } \begin{aligned}
\pi_{t}=[1+\beta]^{-1}\left\{[2+\rho(1+\beta)] \pi_{t-1}\right. \\
\left.-(2 \rho+1) \pi_{t-2}+\rho \pi_{t-3}+\beta \epsilon_{t}\right\} .
\end{aligned}
$$

From this equation we can calculate impulse responses and all moments of inflation.

Consider now the sticky-price model. We find the general solution of these rational expectation models by the method of undetermined coefficients as outlined in Taylor [1985]. Because the money growth rate is stationary, it is a reasonable conjecture that the inflation rate is also stationary and so can be expressed in the $\mathrm{MA}(\infty)$ general form:

$$
\pi_{t}=\sum_{j=0}^{\infty} \phi_{j} \epsilon_{t-j} \quad \text { or } \quad p_{t}=\sum_{k=0}^{\infty} \sum_{j=0}^{\infty} \phi_{j} \epsilon_{t-j-k},
$$

where the $\phi_{j}$ are coefficients to be determined. Then realize that $E_{t}\left\{\epsilon_{t+i-j-k}\right\}=\epsilon_{t+i-j-k}$ for $i-j \leq k$ and is zero otherwise. Using the solution of the model in (A13),

$$
\begin{aligned}
\sum_{k=0}^{\infty} \sum_{j=0}^{\infty} \phi_{j} \epsilon_{t-j-k}=\theta & \sum_{k=0}^{\infty} \sum_{j=0}^{\infty} \phi_{j} \epsilon_{t-1-j-k} \\
& +(1-\theta)^{2} \sum_{i=0}^{\infty} \theta^{i} \sum_{j=0}^{\infty} \sum_{k=\max \{i-j, 0\}}^{\infty} \rho^{j} \epsilon_{t+i-j-k} .
\end{aligned}
$$

But then, because this must hold for all possible realizations of $\epsilon_{t-j}$, matching coefficients on both sides of this equation yields for the coefficient on $\epsilon_{t}$ :

$$
\phi_{0}=(1-\theta)^{2} \sum_{i=0}^{\infty} \theta^{i} \sum_{j=0}^{i} \rho^{j}=\frac{1-\theta}{1-\theta \rho} .
$$

And for a general $v$, the coefficient on $\epsilon_{t-v}$ :

$$
\sum_{j=0}^{v} \phi_{j}=\theta \sum_{j=0}^{v-1} \phi_{j}+(1-\theta)^{2} \sum_{i=0}^{\infty} \theta^{i} \sum_{j=0}^{i+v} \rho^{j} .
$$


This yields

(A26) $\phi_{v}=(\theta-1) \sum_{j=0}^{v-1} \phi_{j}+\left[\frac{(1-\theta)^{2}}{1-\rho}\right]\left[\frac{1}{1-\theta}-\frac{\rho^{v+1}}{1-\theta \rho}\right]$.

Equations (A22), (A24), and (A26) fully describe the stochastic process of inflation. The impulse response of inflation for a unit shock to aggregate demand is given by $\left\{\phi_{v}\right\}$. The autocorrelation coefficients of order $j$ are then given by (see Hamilton [1994], p. 52)

$$
\sum_{v=j}^{\infty} \phi_{v} \phi_{v-j} / \sum_{v=0}^{\infty} \phi_{v}^{2} .
$$

Consider now the sticky-information model. Similarly to (A22), conjecture the solution: $\pi_{t}=\sum \gamma_{i} \epsilon_{t-i}$ or $p_{t}=\sum \sum \gamma_{i} \epsilon_{t-i-k}$, where the sums go from 0 to infinity. Taking the relevant expectations and substituting in (A8), the equation for the Phillips curve, we obtain

$$
\begin{aligned}
\sum_{i=0}^{\infty} \gamma_{i} \epsilon_{t-i} & =\left[\frac{\alpha \lambda}{1-\lambda}\right]\left[\sum_{i=0}^{\infty} \rho^{i} \sum_{k=0}^{\infty} \epsilon_{t-k-i}-\sum_{i=0}^{\infty} \gamma_{i} \sum_{k=0}^{\infty} \epsilon_{t-k-i}\right] \\
& +\lambda \sum_{j=0}^{\infty}(1-\lambda)^{j}\left[(1-\alpha) \sum_{i=j+1}^{\infty} \gamma_{i} \epsilon_{t-i}+\alpha \sum_{i=j+1}^{\infty} \rho^{i} \epsilon_{t-i}\right] .
\end{aligned}
$$

So, again matching coefficients,

$$
\begin{aligned}
\gamma_{0}= & \alpha \lambda /[1-\lambda(1-\alpha)], \\
\gamma_{k}= & \alpha \lambda\left[1-\lambda(1-\alpha) \sum_{i=0}^{k}(1-\lambda)^{i}\right]^{-1} \\
& \times\left[\left(1-\sum_{i=0}^{k-1} \gamma_{i}\right)+\sum_{i=1}^{k} \rho^{i}+\rho^{k} \sum_{i=1}^{k}(1-\lambda)^{i}\right] .
\end{aligned}
$$

This provides the full characterization of the stochastic process for inflation. Impulse responses, autocorrelations, and cross correlations can be easily calculated. 


\section{E. Impulse Responses of Output and Population Correlations between Output and the Change in Inflation}

For the backward-looking model, corr $\left(\pi_{t+2}-\pi_{t-2}, y_{t}\right)=$ corr $\left[\pi_{t+2}-\pi_{t-2},\left(\pi_{t}-\pi_{t-1}\right) / \beta\right]$, which we can evaluate using (A21). Corr $\left(\pi_{t+4}-\pi_{t-4}, y_{t}\right)$ follows likewise.

For the sticky-price model, note that output growth is given from the quantity theory: $\Delta y_{t}=\Delta m_{t}-\pi_{t}=\Sigma\left(\rho^{j}-\phi_{j}\right) \epsilon_{t-j}$. From this, we can obtain the MA( $\infty)$ for output: $y_{t}=\sum \omega_{j} \epsilon_{t-j}$ with the recursion $\omega_{j}=\omega_{j-1}+\rho^{j}-\phi_{j}$, initiated by $\omega_{0}=1-\phi_{0}$. The impulse response to a unit shock is given by the sequence $\left\{\omega_{v}\right\}$. To solve for the change in inflation $\pi_{t}-\pi_{t-4}$, start with $\pi_{t}=\Sigma$ $\phi_{j} \epsilon_{t-j}$; the coefficients in the $\mathrm{MA}(\infty)$ representation for the change in inflation $\pi_{t}-\pi_{t-4}=\sum \xi_{j} \epsilon_{t-j}$ are then given by $\xi_{j}=\phi_{j}-\phi_{j-4}$ with $\xi_{0}=\phi_{0}, \xi_{1}=\phi_{1}, \xi_{2}=\phi_{2}$, and $\xi_{3}=\phi_{3}$. Given these results, the population cross correlation between the change in inflation and output, corr $\left(\pi_{t+2}-\pi_{t-2}, y_{t}\right)$, is

$$
\sum_{v=0}^{\infty} \phi_{v} \xi_{v+2} /\left(\sum_{v=0}^{\infty} \phi_{v}^{2}\right)\left(\sum_{v=0}^{\infty} \xi_{v}^{2}\right) .
$$

The cross-correlation corr $\left(\pi_{t+4}-\pi_{t-4}, y_{t}\right)$ is derived in the same fashion.

The derivation of the population cross correlations in the sticky-information model is precisely the same, except we start with $\pi_{t}=\Sigma \gamma_{i} \epsilon_{t-i}$ as the process for inflation.

DePartment of ECONOMics, HaRVARD University

\section{REFERENCES}

Abel, Andrew B., and Ben S. Bernanke, Macroeconomics, 3rd ed. (Reading, MA: Addison-Wesley, 1998).

Akerlof, George A., and Janet L. Yellen. "A Near-Rational Model of the Business Cycle with Wage and Price Inertia," Quarterly Journal of Economics, C (1985), 823-838.

Ball, Laurence, "Credible Disinflation with Staggered Price Setting," American Economic Review, LXXXIV (1994a), 282-289.

_ "What Determines the Sacrifice Ratio?" in Monetary Policy, N. G. Mankiw, ed. (Chicago, IL: University of Chicago Press, 1994b), pp. 155-182.

_ , "Near Rationality and Inflation in Two Monetary Regimes," NBER Working Paper No. 7988, 2000.

Ball, Laurence, and David Romer, "Real Rigidities and the Non-Neutrality of Money," Review of Economic Studies, LVII (1990), 183-203.

Barro, Robert, "Long-Term Contracting, Sticky Prices, and Monetary Policy," Journal of Monetary Economics, III (1977), 305-316.

Barsky, Robert B., "The Fisher Effect and the Forecastability and Persistence of Inflation," Journal of Monetary Economics, XIX (1987), 3-24. 
Begg, David K. H., and Isabella Imperato, "The Rationality of Information Gathering: Monopoly," The Manchester School, LXIX (2001), 237-252.

Bernanke, Ben S., and Mark Gertler, "Inside the Black Box: The Credit Channel of Monetary Policy Transmission," Journal of Economic Perspectives, IX (1995), 27-48.

Blanchard, Olivier, Macroeconomics, 2nd ed. (Upper Saddle River, NJ: Prentice Hall, 2000).

Blanchard, Olivier, and Nobuhiro Kiyotaki, "Monopolistic Competition and the Effects of Aggregate Demand," American Economic Review, LXXVII (1987), 647-666.

Boschen, John F., and Charles L. Weise, "The Ex Ante Credibility of Disinflation Policy and the Cost of Reducing Inflation," Journal of Macroeconomics, XXIII (2001), 323-347.

Calvo, Guillermo A., "Staggered Prices in a Utility Maximizing Framework," Journal of Monetary Economics, XII (1983), 383-398.

Caplin, Andrew, and Daniel Spulber, "Menu Costs and the Neutrality of Money," Quarterly Journal of Economics, CII (1987), 703-725.

Carroll, Christopher, "The Epidemiology of Macroeconomic Expectations," NBER Working Paper No. 8695, 2001.

Clarida, Richard, Mark Gertler, and Jordi Gali, "The Science of Monetary Policy: A New Keynesian Perspective," Journal of Economic Literature, XXXVII (1999), 1661-1707.

Christiano, Lawrence J., Martin Eichenbaum, and Charles L. Evans, "Modeling Money," NBER Working Paper No. 6371, 1998.

Christiano, Lawrence J., Martin Eichenbaum, and Charles L. Evans, "Monetary Policy Shocks: What Have We Learned and to What End?" Handbook of Macroeconomics, J. B. Taylor and M. Woodford, eds. (Amsterdam, The Netherlands: Elsevier, 1999), pp. 65-148.

Cooper, Russell, and Andrew John, "Coordinating Coordination Failures in Keynesian Models," Quarterly Journal of Economics, CIII (1988), 441-463.

Cover, Thomas M., and Joy A. Thomas, Elements of Information Theory (New York: John Wiley and Sons, 1991).

Dornbusch, Rudiger, Stanley Fischer, and Richard Startz, Macroeconomics, 8th ed. (Boston, MA: McGraw-Hill, 2001).

Fischer, Stanley, "Long-term Contracts, Rational Expectations, and the Optimal Money Supply Rule, Journal of Political Economy, LXXXV (1977), 191-205.

Friedman, Milton, "A Monetary and Fiscal Framework for Economic Stability," American Economic Review, XXXVIII (1948), 279-304.

Fuhrer, Jeffrey, and George Moore, "Inflation Persistence," Quarterly Journal of Economics, CX (1995), 127-160.

Gabaix, Xavier, and David Laibson, "The 6D Bias and the Equity Premium Puzzle," NBER Macroeconomics Annual: 2001 (Cambridge, MA: MIT Press, forthcoming).

Gali, Jordi, and Mark Gertler, "Inflation Dynamics: A Structural Econometric Analysis," Journal of Monetary Economics, XLIV (1999), 195-222.

Gordon, Robert J., "The Time-Varying Nairu and Its Implications for Economic Policy," Journal of Economic Perspectives, XI (1997), 11-32.

Hall, Robert E., and John B. Taylor, Macroeconomics, 4th ed. (New York: Norton, 1993).

Hamilton, James, Time Series Analysis (Princeton, NJ: Princeton University Press, 1994).

Koenig, Evan F., "Aggregate Price Adjustment: The Fischerian Alternative," unpublished paper, 1997.

Lucas, Robert E., Jr., "Econometric Testing of the Natural Rate Hypothesis, in O. Eckstein, ed., The Econometrics of Price Determination (Washington, DC: Board of Governors of the Federal Reserve System, 1972).

- "Some International Evidence on Output-Inflation Tradeoffs," American Economic Review, LXIII (1973), 326-334.

Mankiw, N. Gregory, "Small Menu Costs and Large Business Cycles: A Macroeconomic Model of Monopoly," Quarterly Journal of Economics, C (1985), $529-537$. 
_- "The Inexorable and Mysterious Tradeoff between Inflation and Unemployment," Economic Journal, CXI (2001), C45-C61.

Mankiw, N. Gregory, and Ricardo Reis, "Sticky Information: A Model of Monetary Nonneutrality and Structural Slumps," NBER Working Paper No. 8614, 2001; forthcoming in Knowledge, Information, and Expectations in Modern Macroeconomics: In Honor of Edmund S. Phelps, P. Aghion, R. Frydman, J. Stiglitz, and M. Woodford, eds. (Princeton, NJ: Princeton University Press).

McCallum, Bennett, "Comment," NBER Macroeconomics Annual: 1997 (Cambridge, MA: MIT Press), pp. 355-359.

_- "Stickiness: A Comment," Carnegie-Rochester Conference Series on Public Policy, XLVIII (1998), 357-363.

Moscarini, Giuseppe, "Limited Information Capacity as a Source of Inertia," Yale University, unpublished paper, 2001.

Okun, Arthur M., "Efficient Disinflationary Policies," American Economic Review Papers and Proceedings, LXVIII (1978), 348-352.

Phelps, Edmund S., "Disinflation without Recession: Adaptive Guideposts and Monetary Policy," Weltwirtschaftliches Archiv, C (1978), 239-265.

Rotemberg, Julio, "Monopolistic Price Adjustment and Aggregate Output," Review of Economic Studies, XLIV (1982), 517-531.

Rotemberg, Julio, and Michael Woodford, "An Optimization-Based Econometric Framework for the Evaluation of Monetary Policy," NBER Macroeconomics Annual: 1997 (Cambridge, MA: MIT Press, 1997), pp. 297-346.

Sargent, Thomas J., "The Ends of Four Big Inflations," in Inflation: Causes and Consequences, R. Hall, ed. (Chicago, IL: University of Chicago Press, 1982), pp. 41-97.

_, Macroeconomic Theory, 2nd ed. (New York, NY: Academic Press, 1987).

Sims, Christopher A., "Implications of Rational Inattention," Princeton University, unpublished paper, 2001.

Stock, James H., and Mark W. Watson, "Business Cycle Fluctuations in U. S. Macroeconomic Time Series," Handbook of Macroeconomics, J. B. Taylor and M. Woodford, eds. (Amsterdam, The Netherlands: Elsevier, 1999), pp. 3-64.

Taylor, John B., "Aggregate Dynamics and Staggered Contracts," Journal of Political Economy, LXXXVIII (1980), 1-22.

-New Econometric Approaches to Stabilization Policy in Stochastic Models of Macroeconomic Fluctuations," in Handbook of Econometrics, Vol. 3, Zvi Griliches and M. D. Intriligator, eds. (Amsterdam: North-Holland, 1985), pp. $1997-2055$.

_ - "Staggered Price and Wage Setting in Macroeconomics," Handbook of Macroeconomics, J. B. Taylor and M. Woodford, eds. (Amsterdam, The Netherlands: Elsevier, 1999), pp. 1009-1050.

Woodford, Michael, "Imperfect Common Knowledge and the Effects of Monetary Policy," Princeton University, 2001, forthcoming in Knowledge, Information, and Expectations in Modern Macroeconomics: In Honor of Edmund S. Phelps, P. Aghion, R. Frydman, J. Stiglitz, and M. Woodford, eds. (Princeton, NJ: Princeton University Press).

Zbaracki, Mark J., Mark Ritson, Daniel Levy, Shantanu Dutta, and Mark Bergen, "The Managerial and Customer Costs of Price Adjustment: Direct Evidence from Industrial Markets," unpublished paper, Emory University, 2000. 


\section{This article has been cited by:}

1. Benjamin D. Keen. 2009. THE SIGNAL EXTRACTION PROBLEM REVISITED: A NOTE ON ITS IMPACT ON A MODEL OF MONETARY POLICY. Macroeconomic Dynamics 1. [CrossRef]

2. Jan Libich. 2009. A NOTE ON THE ANCHORING EFFECT OF EXPLICIT INFLATION TARGETS. Macroeconomic Dynamics 13:05, 685. [CrossRef]

3. Ricardo Nunes. 2009. On the Epidemiological Microfoundations of Sticky Information. Oxford Bulletin of Economics and Statistics 71:5, 643-657. [CrossRef]

4. Marika Karanassou, Hector Sala, Dennis J. Snower. 2009. PHILLIPS CURVES AND UNEMPLOYMENT DYNAMICS: A CRITIQUE AND A HOLISTIC PERSPECTIVE. Journal of Economic Surveys . [CrossRef]

5. PATRICK BOLTON, ANTOINE FAURE-GRIMAUD. 2009. Thinking Ahead: The Decision Problem. Review of Economic Studies 76:4, 1205-1238. [CrossRef]

6. David Meenagh, Patrick Minford, Michael Wickens. 2009. Testing a DSGE Model of the EU Using Indirect Inference. Open Economies Review 20:4, 435-471. [CrossRef]

7. Avner Bar-Ilan, Nancy P. Marion. 2009. A Macroeconomic Perspective on Reserve Accumulation. Review of International Economics 17:4, 802-823. [CrossRef]

8. Fernando Alvarez, Andrew Atkeson, Chris Edmond. 2009. Sluggish Responses of Prices and Inflation to Monetary Shocks in an Inventory Model of Money Demand*Sluggish Responses of Prices and Inflation to Monetary Shocks in an Inventory Model of Money Demand*. Quarterly Journal of Economics 124:3, 911-967. [Abstract] [PDF] [PDF Plus]

9. Ricardo Reis. 2009. Optimal Monetary Policy Rules in an Estimated Sticky-Information Model. American Economic Journal: Macroeconomics 1:2, 1-28. [CrossRef]

10. Stefano DellaVigna. 2009. Psychology and Economics: Evidence from the Field. Journal of Economic Literature 47:2, 315-372. [CrossRef]

11. Bartosz Maćkowiak, Mirko Wiederholt. 2009. Optimal Sticky Prices under Rational Inattention. American Economic Review 99:3, 769-803. [CrossRef]

12. GUIDO LORENZONI. 2009. Optimal Monetary Policy with Uncertain Fundamentals and Dispersed Information. Review of Economic Studies . [CrossRef]

13. Ricardo Nunes. 2009. LEARNING THE INFLATION TARGET. Macroeconomic Dynamics 13:02, 167. [CrossRef]

14. CARLOS CAPISTRÁN, ALLAN TIMMERMANN. 2009. Disagreement and Biases in Inflation Expectations. Journal of Money, Credit and Banking 41:2-3, 365-396. [CrossRef] 
15. Christopher Douglas, Ana María Herrera. 2009. Why are gasoline prices sticky? A test of alternative models of price adjustment. Journal of Applied Econometrics $\mathrm{n} / \mathrm{a}-\mathrm{n} / \mathrm{a}$. [CrossRef]

16. CHRISTIAN HELLWIG, LAURA VELDKAMP. 2009. Knowing What Others Know: Coordination Motives in Information Acquisition. Review of Economic Studies 76:1, 223-251. [CrossRef]

17. William A. Branch, John Carlson, George W. Evans, Bruce McGough. 2009. Monetary Policy, Endogenous Inattention and the Volatility Trade-off*. The Economic Journal 119:534, 123-157. [CrossRef]

18. Oleg Korenok, Stanislav Radchenko, Norman R. Swanson. 2009. International evidence on the efficacy of new-Keynesian models of inflation persistence. Journal of Applied Econometrics n/a-n/a. [CrossRef]

19. MARIKA KARANASSOU, HECTOR SALA, DENNIS J. SNOWER. 2009. THE EVOLUTION OF INFLATION AND UNEMPLOYMENT: EXPLAINING THE ROARING NINETIES. Australian Economic Papers 47:4, 334-354. [CrossRef]

20. Emi Nakamura, Jón Steinsson. 2008. Five Facts about Prices: A Reevaluation of Menu Cost Models*Five Facts about Prices: A Reevaluation of Menu Cost Models*. Quarterly Journal of Economics 123:4, 1415-1464. [Abstract] [PDF] [PDF Plus] [Supplementary material]

21. JÖRG DÖPKE, JONAS DOVERN, ULRICH FRITSCHE, JIRI SLACALEK. 2008. Sticky Information Phillips Curves: European Evidence. Journal of Money, Credit and Banking 40:7, 1513-1520. [CrossRef]

22. Luca Benati. 2008. Investigating Inflation Persistence Across Monetary Regimes*Investigating Inflation Persistence Across Monetary Regimes*. Quarterly Journal of Economics 123:3, 1005-1060. [Abstract] [PDF] [PDF Plus]

23. Peter J. Klenow, Oleksiy Kryvtsov. 2008. State-Dependent or Time-Dependent Pricing: Does It Matter for Recent U.S. Inflation?*State-Dependent or Time-Dependent Pricing: Does It Matter for Recent U.S. Inflation?*. Quarterly Journal of Economics 123:3, 863-904. [Abstract] [PDF] [PDF Plus]

24. CHENGSI ZHANG, DENISE R. OSBORN, DONG HEON KIM. 2008. The New Keynesian Phillips Curve: From Sticky Inflation to Sticky Prices. Journal of Money, Credit and Banking 40:4, 667-699. [CrossRef]

25. Mark Bergen, Daniel Levy, Sourav Ray, Paul H. Rubin, Benjamin Zeliger. 2008. When Little Things Mean a Lot: On the Inefficiency of Item-Pricing Laws. The Journal of Law and Economics 51:2, 209-250. [CrossRef]

26. Ernst Fehr, Jean-Robert Tyran. 2008. Limited Rationality and Strategic Interaction: The Impact of the Strategic Environment on Nominal Inertia. Econometrica 76:2, 353-394. [CrossRef]

27. Piero Ferri. 2007. THE LABOUR MARKET AND TECHNICAL CHANGE IN ENDOGENOUS CYCLES. Metroeconomica 58:4, 609-633. [CrossRef] 
28. Peter Flaschel, Göran Kauermann, Willi Semmler. 2007. TESTING WAGE AND PRICE PHILLIPS CURVES FOR THE UNITED STATES. Metroeconomica 58:4, 550-581. [CrossRef]

29. Michael C. Davis. 2007. The dynamics of daily retail gasoline prices. Managerial and Decision Economics 28:7, 713-722. [CrossRef]

30. ICHIRO FUKUNAGA. 2007. Imperfect Common Knowledge, Staggered Price Setting, and the Effects of Monetary Policy. Journal of Money, Credit and Banking 39:7, 1711-1739. [CrossRef]

31. Rajesh Chakrabarti, Barry Scholnick. 2007. The mechanics of price adjustment: new evidence on the (un)importance of menu costs. Managerial and Decision Economics 28:7, 657-668. [CrossRef]

32. Luca Fanelli. 2007. Testing the New Keynesian Phillips Curve Through Vector Autoregressive Models: Results from the Euro Area. Oxford Bulletin of Economics and Statistics, ahead of print070921170652009-???. [CrossRef]

33. James Yetman. 2007. Explaining hump-shaped inflation responses to monetary policy shocks. Managerial and Decision Economics 28:6, 605-617. [CrossRef]

34. IVAN PAYA, AGUSTIN DUARTE, KEN HOLDEN. 2007. On the Relationship between Inflation Persistence and Temporal Aggregation. Journal of Money, Credit and Banking 39:6, 1521-1531. [CrossRef]

35. Daniel Levy. 2007. Price rigidity and flexibility: recent theoretical developments. Managerial and Decision Economics 28:6, 523-530. [CrossRef]

36. Alexander L. Wolman. 2007. The frequency and costs of individual price adjustment. Managerial and Decision Economics 28:6, 531-552. [CrossRef]

37. OLEG KORENOK, NORMAN R. SWANSON. 2007. How Sticky Is Sticky Enough? A Distributional and Impulse Response Analysis of New Keynesian DSGE Models. Journal of Money, Credit and Banking 39:6, 1481-1508. [CrossRef]

38. Campbell Leith, Jim Malley. 2007. A Sectoral Analysis of Price-Setting Behavior in U.S. Manufacturing IndustriesA Sectoral Analysis of Price-Setting Behavior in U.S. Manufacturing Industries. Review of Economics and Statistics 89:2, 335-342. [Abstract] [PDF] [PDF Plus]

39. Alexis Anagnostopoulos, Omar Licandro, Italo Bove, Karl Schlag . 2007. An Evolutionary Theory of Inflation InertiaAn Evolutionary Theory of Inflation Inertia. Journal of the European Economic Association 5:2-3, 433-443. [Abstract] [PDF] [PDF Plus]

40. N. Gregory Mankiw , Ricardo Reis . 2007. Sticky Information in General EquilibriumSticky Information in General Equilibrium. Journal of the European Economic Association 5:2-3, 603-613. [Abstract] [PDF] [PDF Plus]

41. Kajal Lahiri, Fushang Liu. 2007. Modelling multi-period inflation uncertainty using a panel of density forecasts. Journal of Applied Econometrics 21:8, 1199-1219. [CrossRef] 
42. RICARDO REIS. 2006. Inattentive Producers. Review of Economic Studies 73:3, 793-821. [CrossRef]

43. Ignazio Angeloni, Luc Aucremanne, Matteo Ciccarelli. 2006. Price setting and inflation persistence: did EMU matter?. Economic Policy 21:46, 353-387. [CrossRef]

44. Ignazio Angeloni, Luc Aucremanne, Michael Ehrmann, Jordi Galí, Andrew Levin , Frank Smets . 2006. New Evidence on Inflation Persistence and Price Stickiness in the Euro Area: Implications for Macro ModelingNew Evidence on Inflation Persistence and Price Stickiness in the Euro Area: Implications for Macro Modeling. Journal of the European Economic Association 4:2-3, 562-574. [Abstract] [PDF] [PDF Plus]

45. Alfred V. Guender. 2006. Stabilising Properties of Discretionary Monetary Policies in a Small Open Economy*. The Economic Journal 116:508, 309-326. [CrossRef]

46. Oleg Korenok, Norman R. Swanson. 2006. The Incremental Predictive Information Associated with Using Theoretical New Keynesian DSGE Models vs. Simple Linear Econometric Models*. Oxford Bulletin of Economics and Statistics 67:s1, 905-930. [CrossRef]

47. AARON L. JACKSON. 2005. DISINFLATIONARY BOOM REVERSION. Macroeconomic Dynamics 9:04. . [CrossRef]

48. Peter McAdam, Alpo Willman. 2004. Supply, Factor Shares and Inflation Persistence: Re-examining Euro-area New-Keynesian Phillips Curves*. Oxford Bulletin of Economics and Statistics 66:s1, 637-670. [CrossRef]

49. Mark J. Zbaracki , Mark Ritson, Daniel Levy, Shantanu Dutta , Mark Bergen . 2004. Managerial and Customer Costs of Price Adjustment: Direct Evidence from Industrial MarketsManagerial and Customer Costs of Price Adjustment: Direct Evidence from Industrial Markets. Review of Economics and Statistics 86:2, 514-533. [Abstract] [PDF] [PDF Plus]

50. John C. Driscoll , Steinar Holden . 2004. Fairness and Inflation PersistenceFairness and Inflation Persistence. Journal of the European Economic Association 2:2-3, 240-251. [Abstract] [PDF] [PDF Plus]

51. Steinar Holden, John C Driscoll. 2003. Inflation Persistence and Relative Contracting. American Economic Review 93:4, 1369-1372. [CrossRef]

52. N. Gregory Mankiw , Ricardo Reis . 2003. What Measure of Inflation Should a Central Bank Target? What Measure of Inflation Should a Central Bank Target?. Journal of the European Economic Association 1:5, 1058-1086. [Abstract] [PDF] [PDF Plus]

53. Christopher D. Carroll . 2003. Macroeconomic Expectations Of Households And Professional Forecasters*Macroeconomic Expectations Of Households And Professional Forecasters*. Quarterly Journal of Economics 118:1, 269-298. [Abstract] [PDF] [PDF Plus] 
54. Kajal Lahiri, Fushang LiuARCH Models for Multi-period Forecast Uncertainty: A Reality Check Using a Panel of Density Forecasts 321-363. [CrossRef] 